\title{
Cost Structure Analysis in Inter Island Perishable Goods Transport (Case Study: South Konawe Citrus, Southeast Sulawesi, Indonesia)
}

\section{Kuncoro Harto Widodo ${ }^{1}$ and Dwi Ardianta Kurniawan²}

${ }^{1}$ Department of Agro-Industrial Technology, Faculty of Agricultural Technology, Gadjah Mada University, Jl. Flora No.1 Bulaksumur 55281, Indonesia

${ }^{2}$ Center for Transportation and Logistics Studies, Gadjah Mada University, Jl. Kemuning M-3, Sekip, Sleman, DIY, 55281, Indonesia

Abstract The objectives of this paper are to measure prices and costs on the supply chains of fresh oranges products. It also qualitatively investigates supply chain bottlenecks and their impact in terms of access toward markets for small producers in rural areas. The analysis of supply-chain bottlenecks is focusing on the breakdown of

Corresponding Author Kuncoro Harto Widodo kuncorohw@yahoo.com

Received: 25 December 2017 Accepted: 5 February 2018 Published: 1 March 2018

Publishing services provided by Knowledge E

(c) Kuncoro Harto Widodo and Dwi Ardianta Kurniawan. This article is distributed under the terms of the Creative

which permits unrestricted use and redistribution provided that the original author and source are credited.

Selection and Peer-review under the responsibility of the ICoA Conference Committee.

\section{S OPEN ACCESS} costs (production, post-harvest, and logistics (transport)) within the supply chain. The location study is in South Konawe-, Southeast Sulawesi, Indonesia which is known as one of the largest citrus producer in Indonesia.

The results show that the formation of the price of oranges is formed with the following characteristics: 1) cost at the farm level is made up of costs for production activities and processing activities are not done because orange is sold in the form of raw materials, 2) factors that affect the cost at the trade level is the infrastructure condition, mileage and processes during delivery, and 3 ) the selling price is determined by the trader in accordance with market demand. Merchants were indicated to have the power to determine the prices are a big trader in Java, with implications for the pricing down to the farm level. The condition of infrastructure is an important aspect in the formation of prices. Badly damaged roads often cause farmers cannot sell their production to other regions because of the high risk of damage to goods due mired vehicles on the road, as well as a long time transporting. Another issue that arises is related to inadequate governance in the Port of Kendari, Southeast Sulawesi which caused the cost of transportation by the port to be expensive. The existence of interests of the parties that play a role in making the port of unloading handling process becomes inefficient. High price made by the association of workers unloading for example, makes the high cost of handling goods. Not to mention the imbalance in the flow of goods in and out of the Port of Kendari, mainly from Java, which caused the vessel operator must take into account the condition of empty when the ship returned in Java. Another condition is a problem with the transport of goods is the last priority given to freight transport compared to passenger transport. This often makes long waiting times at the port, which will affect the transported goods, especially perishables goods such as fruits. Generally this indicates inefficient trading patterns oranges in South Konawe requiring further intervention of the various parties concerned. 


\section{INTRODUCTION}

In coming years, Indonesia is predicted to import food to meet its domestic needs. The price instability and dependency to imported food is not only for staple food but also for the commodity that more demanded specifically by a rising economy group, such as fruit commodities. Currently, Indonesia becomes the second largest importer of fresh orange in ASEAN after Malaysia. From 2005 to 2009, Indonesia had imported 127,041 ton of sweet orange in total, or 25,408 on average per year, with total value of US\$17,464,186 per year. For mandarin orange for the same period, Indonesia had imported 504,063 tons in total or 100,813 ton per year with total value of US\$ 80,569,300 per year (BPS, 2012: Processed data).

On the other hand, some regions in Indonesia have had superior agricultural commodities that have the trade mark to exist in the trade, such as medan and pontianak orange, indramayu mango, delanggu rice and so on. In addition,some regions are also developing various commodity that is expected to compete with products from other areas, both national and global. We can mention for example citrus commodities in Jember and Sulawesi, so currently known with name of sulawesi and jember orange.

Therefore, national program to more self-sustaining agriculture commodities to supply domestic market has been challenged by current global free trade market mechanism. The establishment of ASEAN and China free trade area had caused fresh orange commodity coming from China could get into Indonesia with lower price and larger availability compared to domestic orange. The condition had significant impact to discouraging local production and reducing the competitiveness of local commodities. Without a strategic intervention, this situation would lead national food insecurity. Fruit and perishable goods trade policy need to pay attention to aspects of the availability of infrastructure [3] and the commodity supply chain management [4]. The flow of commodities from the point of origin to the destination of business chain needs supply chain manegement to optimize the requirements of each entities along the chain [1], [6], [9] and [10].

The objectives of this paper is to measure prices and costs on the supply chains of fresh oranges products. It also qualitatively investigates supply chain bottlenecks and their impact in terms of access toward markets for small producers in rural areas. The analysis of supply-chain bottlenecks is focusing on the breakdown of costs (production, 


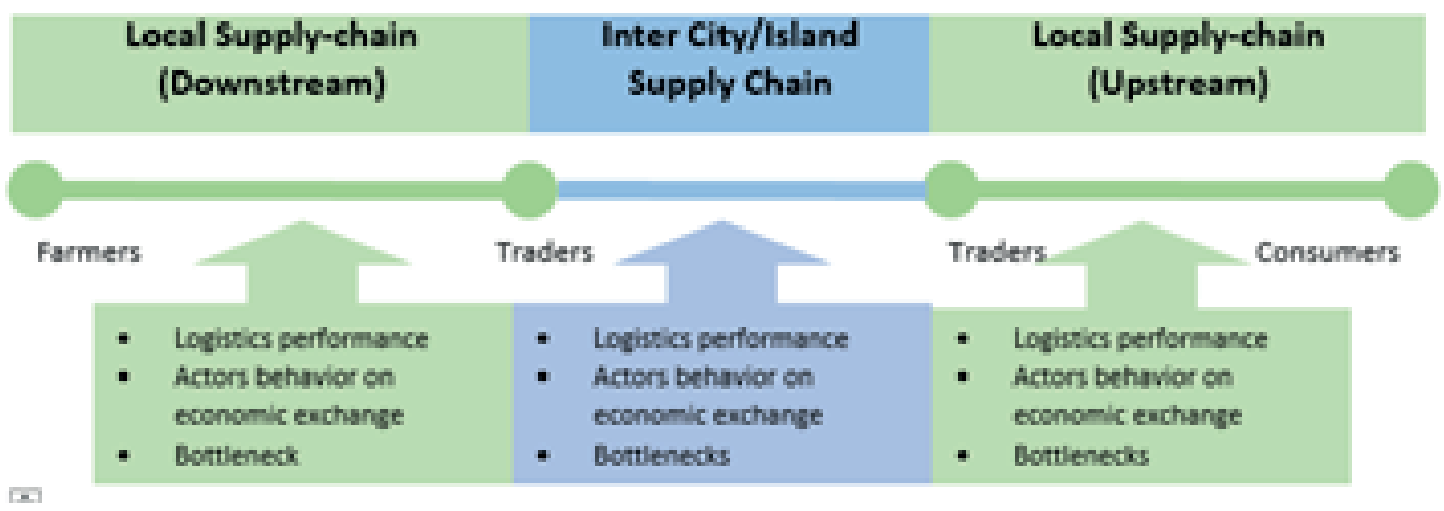

Figure 1: Study Approach.

post-harvest, and logistics (transport)) within the supply chain. The location study is in Konawe South, Southeast Sulawesi, which is known as one of the largest citrus producer in Indonesia [2], [5].

\section{METHOD}

To achieve the above objectives, logistics performance study has been done. This methodology track key performance indicators of time, costs and distance on every segment within commodity supply-chain. Quantitative data is to helps identify key bottlenecks within the supply chain. Whereas the use of qualitative data it to help explains cause of bottleneck within the supply chain. Thus the work focuses on the logistics of food production and distribution and the associated institutional arrangements for specific supply chains.

We then measure all the cost especially production cost and logistics cost, then calculate the price in each entity and complete the margin between the price and the cost. The result of the calculation is very important to obtain information of the condition in each player, the adjacent player until the ultimate player (see Figure 1). From this, we can examine the possible bottleneck and elaborate the main causes. This will also help understanding to the representation of the behavior of the rural supply chain. For this, we incorporate "the life-cycle of economic approach" between any certain farmer to adjacent entity which includes the following steps: (1) search and selection of the partner to know how do the buyers select their suppliers and how do they conceptualize suppliers to minimize risk, (2) negotiating and contracting between the partners, (3) contract execution and performance, and (4) rules of market relations which maybe in the form of regulation or consensus. 


\section{RESULT}

The field survey has included key stakeholders in the distribution channel and commodity trade which include farmer, processor, trader, logistics service provider and consumer. For the purpose of selecting location of data collection in farmer level, study team has coordinated with local agriculture agency. Farmer locations for primary data collection are determined by regional productivity. Data are collected in the centers of commodity production.

In South Konawe Regency, the survey for fresh orange commodity has involved eleven farmers, thirteen traders, two logistic service providers, and three consumers. We identified four main trade routes in this area, i.e:

1. Line 1 includes distribution line of fresh orange from Wolasi sub-district.

2. Line 2 includes distribution line from Konda sub-district.

3. Line 3 includes distribution of orange from Buke sub-district.

4. Line 4 includes distribution of orange from Lalembuu sub-district, which is the center of orange in South Konawe.

Orange trading activity in South Konawe includes some major players, including farmers, collectors, wholesalers (inter-island trader), trader, retailer and consumer. In South Konawe there are only few wholesalers. Orange trading activities are concentrated in Lalembuu sub-district as the oldest and largest orange production center in South Konawe[7], [8]. Most of the orange in South Konawe are sold to other islands, such as Java (Surabaya), through the Port of Kendari. The proportion reached 90\%. Meanwhile, orange are also sold to other provinces in Sulawesi Island, such as South Sulawesi (Makassar) as well as to local market, with proportion of $5 \%$ each.

Based on production data, interview with officers of Agriculture Agency in the regency, and consideration on accessibility to the potential study location in the regency, the study team has selected Lalembuu, Wolasi, Buke and Konda sub-districts as the study locations [7], [8]. In addition, the selection of location also considers the existence of big traders of fresh orange in which most of them are located in Lalembuu sub-districts. The sub-district has become the pioneer of orange plantation in South Konawe.

Price and cost formation in each route identified as follows:

1. Line 1: In farmer level, the cost is for production activity. There is no processing cost since orange is sold as it is. Factors affecting the cost in trader level 

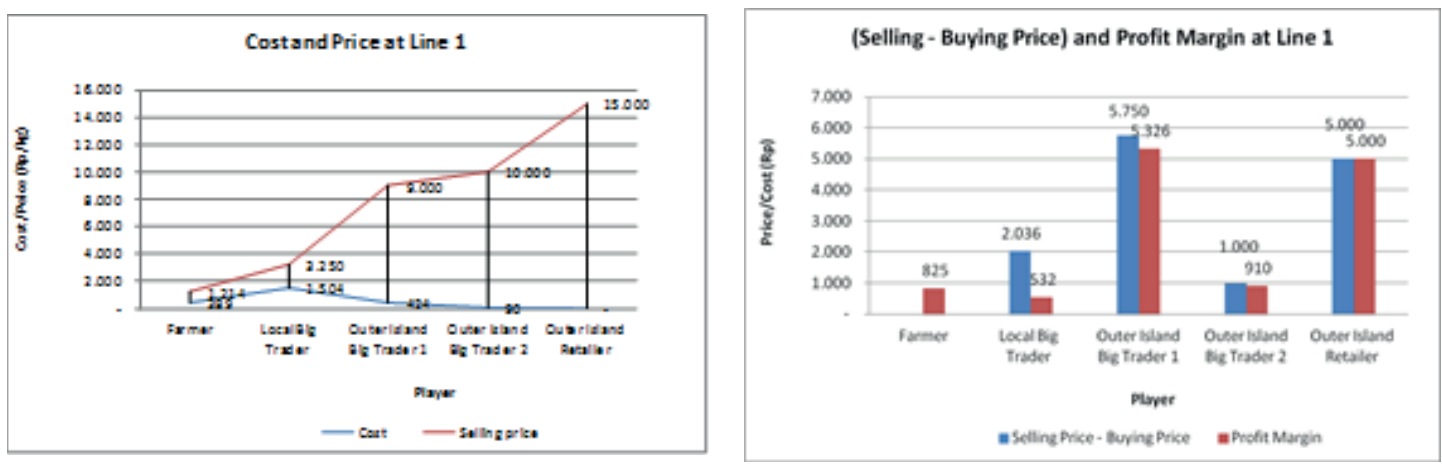

Figure 2: Cost, price and profit margin in Line 1.

include infrastructure condition, travel distance, and distribution time. Selling price is determined by trader in line with the market demand. Traders who are identified to have power in determining price are big trader in Java Island which subsequently has implication in the determination of price until farmer level.

2. Line 2: The formation of cost and price in Konda is relatively the same as that in Wolasi. However, the distribution cost from Konda to Kendari is lower since the distance is shorter and the infrastructure is relatively good.

3. Line 3: Road infrastructure is in definitely bad condition which may increase the risk of transportation to Kendari. Selling price is determined by trader.

4. Line 4: Definitely poor condition of road infrastructure has made farmers not being able to sell their production to outside the area. The main reason is that high risk of damage during the transportation. In addition to taking long time, the vehicles are sometime tumbled or stuck. Price is determined by considering the offer as presented by big trader in Surabaya. Sometimes, the offering price is lower as there are some options of orange in Surabaya, for example orange from Jember.

To be comparable, the study only analyzes the inter-island routes, in this case headed to Java. Cost, price and profit margin of orange commodity at each line described as follows Figures 2, 3, 4, and 5:

The above pictures illustrate that the greatest profit by unit (per $\mathrm{kg}$ ) received by retailers across the island, followed by inter-island trader. Meanwhile, farmers and wholesalers in the local level receive a smaller profit, with variations depending on the location of production that affect the cost of transport to the port. Nevertheless, the total inter-island traders totally received the biggest profit, due to the large volume of trade conducted. 

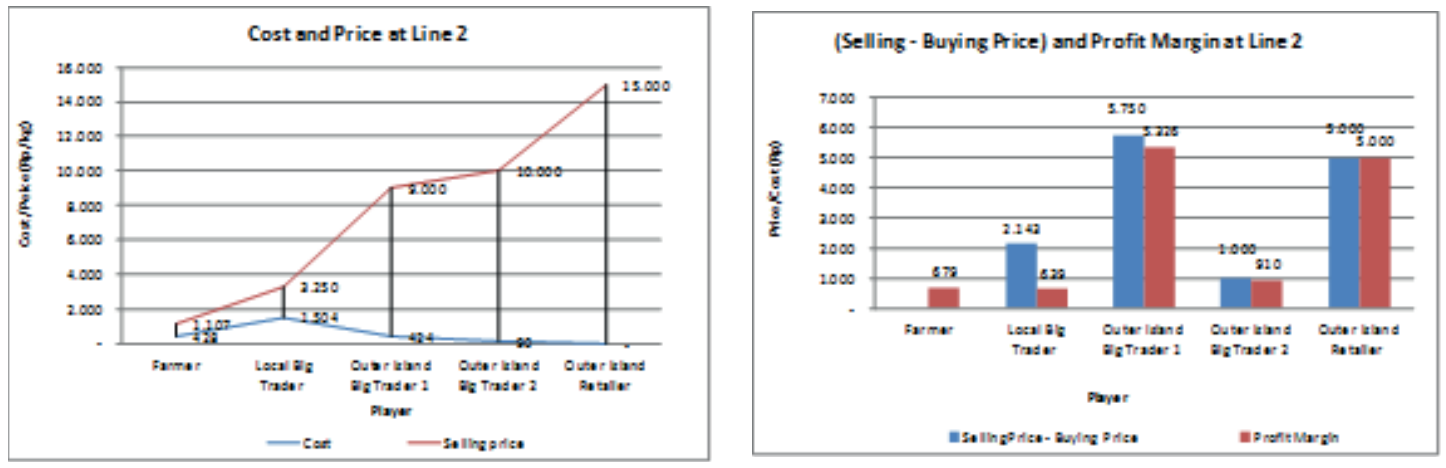

Figure 3: Cost, price and profit margin in Line 2.
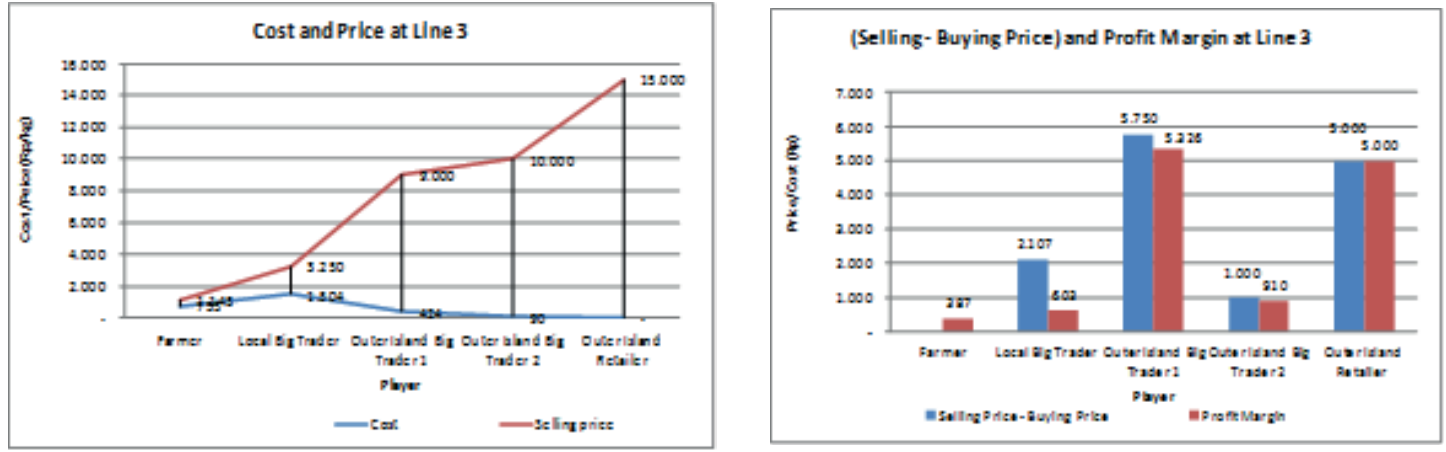

Figure 4: Cost, price and profit margin in Line 3.
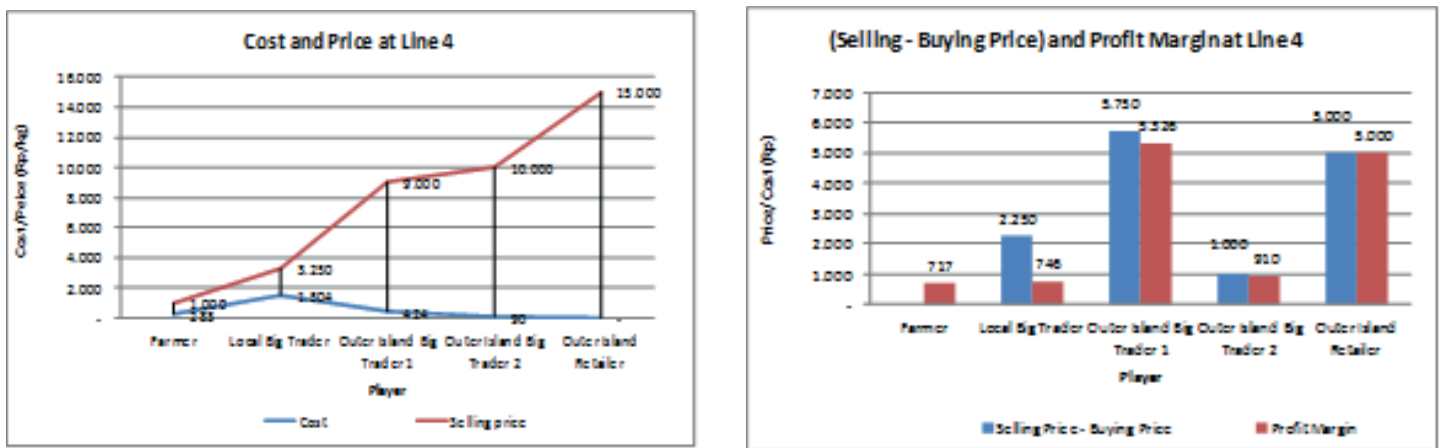

Figure 5: Cost, price and profit margin in Line 4 (Source: field survey (2013), processed).

More in-depth study of the cost structure shows the following results:

Table 1 illustrates that the greatest costs incurred for logistics cost, the average reached $78.5 \%$. The magnitude of logistics costs vary depending on the location of the production that will affect the cost of transport. More detail, the identification shows that the largest portion of logistics cost is to transport, which reached more than $98 \%$ proportion. 
TABLE 1: Cost Structure of Orange Trade in Konawe Selatan.

\begin{tabular}{|c|c|c|c|c|c|c|c|c|}
\hline \multirow[t]{3}{*}{ Line Description } & \multicolumn{8}{|c|}{ Cost } \\
\hline & \multicolumn{4}{|c|}{$\ln \mathrm{Rp}$} & \multicolumn{4}{|c|}{$\ln \%$} \\
\hline & $\begin{array}{l}\text { Production } \\
\text { Cost }\end{array}$ & $\begin{array}{l}\text { Post- } \\
\text { Harvest } \\
\text { Cost }\end{array}$ & $\begin{array}{l}\text { Logistics } \\
\text { (Trans- } \\
\text { port) } \\
\text { Cost }\end{array}$ & $\begin{array}{l}\text { Total } \\
\text { Cost }\end{array}$ & $\begin{array}{c}\text { Production } \\
\text { Cost }\end{array}$ & $\begin{array}{l}\text { Post- } \\
\text { Harvest } \\
\text { Cost }\end{array}$ & $\begin{array}{l}\text { Logistics } \\
\text { (Trans- } \\
\text { port) } \\
\text { Cost }\end{array}$ & $\begin{array}{l}\text { Total } \\
\text { Cost }\end{array}$ \\
\hline $\begin{array}{l}1 \text { Wolasi - Kendari - } \\
\text { Surabaya - } \\
\text { Yogyakarta - } \\
\text { Sleman }\end{array}$ & 389 & - & 1.928 & 2.317 & $16,8 \%$ & $0,0 \%$ & $83,2 \%$ & $100,0 \%$ \\
\hline $\begin{array}{l}2 \text { Konda - Kendari - } \\
\text { Surabaya - } \\
\text { Yogyakarta - } \\
\text { Sleman }\end{array}$ & 447 & - & 1.504 & 1.951 & $22,9 \%$ & $0,0 \%$ & $77,1 \%$ & $100,0 \%$ \\
\hline $\begin{array}{l}3 \text { Buke - Kendari - } \\
\text { Surabaya - } \\
\text { Yogyakarta - } \\
\text { Sleman }\end{array}$ & 755 & - & 1.504 & 2.259 & $33,4 \%$ & $0,0 \%$ & $66,6 \%$ & $100,0 \%$ \\
\hline $\begin{array}{l}4 \text { Lalembuu - } \\
\text { Kendari - } \\
\text { Surabaya - } \\
\text { Yogyakarta - } \\
\text { Sleman }\end{array}$ & 283 & - & 1.928 & 2.211 & $12,8 \%$ & $0,0 \%$ & $87,2 \%$ & $100,0 \%$ \\
\hline Average & 469 & - & 1.716 & 2.185 & $21,5 \%$ & $0,0 \%$ & $78,5 \%$ & $100,0 \%$ \\
\hline
\end{tabular}

\section{DISCUSSION}

The results show that the formation of the price of oranges is formed with the following characteristics:

1. Cost at the farm level is made up of costs for production activities. Processing activities are not done because orange is sold in the form of raw materials.

2. Factors that affect the cost at the trade level is the infrastructure condition, mileage and processes during delivery,

3. The selling price is determined by the trader in accordance with market demand. Merchants were indicated to have the power to determine the price are a big trader in Java, with implications for the pricing down to the farm level.

The condition of infrastructure is an important aspect in the formation of prices. Badly damaged roads often cause farmers can not sell their production to other regions because of the high risk of damage to goods due mired vehicles on the road, as 
well as a long time transporting. Another issue that arises is related to inadequate governance in the Port of Kendari, which caused the cost of transportation by the port to be expensive. The existence of interests of the parties that play a role in making the port of unloading handling process becomes inefficient. High price made by the association of workers unloading for example, makes the high cost of handling goods. Not to mention the imbalance in the flow of goods in and out of the Port of Kendari, mainly from Java, which caused the vessel operator must take into account the condition of empty when the ship returned in Java. Another condition is a problem with the transport of goods is the last priority given to freight transport compared to passenger transport. This often makes long waiting times at the port, which will affect the transported goods, especially perishables goods such as fruits.

Generally this indicates inefficient trading patterns oranges in South Konawe requiring further intervention of the various parties concerned.

\section{CONCLUSIONS}

The following are the results of the study:

1. Conditions of transportation is a limiting factor in the marketing of citrus production from South Konawe, both derived from the poor quality of road and port governance.

2. In regional terms, the imbalance of the volume to the out of area production led to high cost of freight to other regions because of the empty cargo that must be calculated as cost.

\section{ACKNOWLEDGEMENT}

We express our gratitude to the World Bank which has given the trust to conduct the study. Moreover thanks go to the management and a team of experts from the Center for Transportation and Logistics Studies (Pustral) Gadjah Mada University who has provided the opportunity and contribute to the implementation of the study.

\section{References}

[1] Beamon, B. M. 2008. Sustainability and Future of Supply Chain Management. Journal Operations and Supply Chain Management 1(1), pp. 4-18. 
[2] Central Bureau of Statistics the Republic of Indonesia. 2011. The National Economic Social Survey. Jakarta

[3] FE van Dyk, Maspero, E. 2004. An analysis of the South African fruit logistics infrastructure. OriON, Volume 20 (1), pp. 55-72, http://www.orssa.org.za, http://economy.okezone.com/read/2013/02/23/320/ 766412/kenapa-jeruk-medan-lebih-mahal-dari-jeruk-mandarin

[4] Ministry of Agriculture. 2015. Agricultural Statistics Database. Jakarta

[5] Karaan, M., Ham, C. Akinnifesi, F., Moombe, K., Jordaan, D., Franzel, S., and Aithal, A. 2005. Baseline Marketing Surveys and Supply Chain Studies for Indigenous Fruit Markets in Tanzania, Zimbabwe and Zambia., World Agroforestry Centre and CPWild Research Alliance

[6] Simchi-Levi, D., Kaminisky, P. and Simchi-Levi, E. 2000. Design and Managing the Supply Chain: Concept, Strategies, and Case Studies. McGraw-Hill Higher Education, USA, pp. 1-13.

[7] South Konawe District Agriculture Office. 2013. Data Production Fruit Crops in Konsel

[8] The Central Bureau of Statistics of Southeast Sulawesi Province. 2013. Southeast Sulawesi in Figures 2013.

[9] Widodo, K. H. 2003. A Need of Supply Chain Management Models for Agricultural Fresh Products as a Perishable Item based on Its Properties and Literature Review. Prosiding the $12^{\text {th }}$ Indonesian Scientific Meeting, Osaka University, Pp. 576-580.

[10] Widodo, K. H., Pramudya, K., and Abdullah, A. 2011. Supply Chain Management for Sustainable Agroindustry (in Bahasa Indonesia). Lubuk Agung Press. Bandung. 